\title{
ПСИХОЛІНГВАЛЬНІ ЧИННИКИ ФУНКЦІОНУВАННЯ СЛЕНГОВИХ ОДИНИЦЬ
}

\author{
ОКСАНА ТАРАН \\ Харківський національний педагогічний університет імені Г. С. Сковороди, \\ Харків - Україна \\ PSYCHOLINGWISTYCZNE CZYNNIKI \\ FUNKCJONOWANIA SLANGU

\section{OKSANA TARAN} \\ Charkowski Narodowy Uniwersytet Pedagogiczny im. H. Skoworody, \\ Charków — Ukraina
}

STRESZCZENIE. W artykułe dokonana została analiza teoretyczna psycholingwistycznych czynników funkcjonowania slangu. Scharakteryzowano takie czynniki, jak: asocjacja, myślenie określonymi kategoriami, wolność werbalna. Ponadto przeanalizowano psychologiczne podłoże użycia leksyki obscenicznej i leksyki slangu jako eufemizmów.

\section{PSYCHOLINGUISTIC FACTORS \\ OF SLANG WORDS FUNCTIONING}

OKSANA TARAN

H. S. Skovoroda Kharkiv National Pedagogical University, Kharkiv — Ukraine

ABSTRACT. The article focuses on the psycholinguistic aspect of slang words functioning. Such psycholinguistic factors as association, thinking by categories, verbal freedom are described in the article. Also the author determines general psychological nature of the use of vulgar vocabulary and slang euphemisms.

$\mathrm{Y}$

зв’язку з поширенням у мовленні одиниць різних соціолектів, що при цьому набувають семантичних змін, визначаємо таку лексико-фразеологічну підсистему мови, як загальний сленг, одиниці якого добре відомі та вживані широкими верствами населення - незалежно від соціопрофесійних характеристик, зокрема й носіями літературної мови. Однак функції загального сленгу відмінні від арго або професійно-корпоративних жаргонів, за рахунок одиниць яких він поповнюється. Очевидно, це пов'язано з їхньою соціальною природою та тими психологічними механізмами, що лежать в їх основі. Так, арго $є$ соціолектом закритої соціальної групи, для якої М. Грачов визначає такі функції¹

- конспіративну (залежить від комунікативної мети - або втаємничити свої дії та наміри, напр., попередити про небезпеку, дізнатися про хід справ тощо, або, навпаки, показати належність до кримінального світу). Щоправда, не всі лінгвісти поділяють цей погляд, зокрема Д. Лихачов був категорично проти визначення конспіративної функції в арго, оскільки звичайне мовлення крадія так само природне й неумовне, як мовлення представника кожної іншої со-

${ }^{1}$ М. А. Грачёв , Русское арго, Нижний Новгород 1997, с. 94-153. 
ціальної групи². Існує думка, що хизуються знанням арго здебільшого підлітки, однак, як зауважує М. Грачов, їхнє мовлення виявляє високу частотність уживання арготизмів, проте низьку їх кількість, тобто доволі обмежену частку арготичної лексики, переважно загальнокримінальної і трохи тюремної;

- розпізнавальну (з'явилася внаслідок еволюції злочинності, збільшення міст; зумовлена прагненням до відокремлення й протиставлення себе законослухняним громадянам; іiі специфіка полягає в сприянні більш тісної консолідації криміногенного угруповання й недопущенні до свого середовища ворожих елементів);

- номінативну (первісно була домінантною, бо зумовлена необхідністю називати реалії кримінального світу, що не мали відповідників ані в літературній мові, ані в просторіччі - таких одиниць у спеціалізованих арго 89\%);

- світоглядну (поєднує всі декласовані елементи в один соціум).

Д. Лихачов називає таку головну відмінність мислення представників кримінального світу, як відродження елементів магічного ставлення до світу, прихований магічний аспект мовлення злодіїв „виражений в його емоційноекспресивній насиченості". У зв'язку із цим, заслуговує на увагу таке спостереження дослідника: мовлення злодія завжди піднесене, а зниження й вульгарність цього мовлення - це особливість нашого сприйняття. Лінгвіст також указує на превалювання аперцептивного процесу (мовлення злодіїв виконує насамперед сигнальну функцію) ${ }^{4}$

Корпоративний сленг (жаргон) є субстандартною підсистемою відкритої соціальної групи (шкільний, молодіжний, студентський сленг, сленг байкерів, сленг хіпі тощо). Л. Радзиховський і А. Мазурова характеризують „системний” сленг такими функціями: 1) шифрувальна (на ії реалізацію спрямована лексика на позначення реалій і понять, які слід приховати від „чужих”, тобто тих, хто не в „Системі”, — це переважно слова, пов'язані з уживанням наркотиків), 2) розпізнавальна (для розмежування „своїх" і „чужих” — це, напр., назви традиційно хіповських прикрас), 3) естетична (сленг як спосіб розфарбувати похмуру дійсність), 4) лінгвокреативна (сленг дає простір для вияву індивідуальних особливостей мовця $)^{5}$. Н. Шовгун серед чинників, що стимулюють формування групового сленгу, називає „бажання створити додаткову ідентифікуючу ознаку, яка б виконувала роль соціального символу і на основі якої можна було б здійснювати поділ на „своїх” (тих, хто володіє даним сленгом) і „чужих” (чиє мовлення відрізняється від мовлення даної групи)"6. Фактично це розпізнавальна функція сленгу, але, напр., у студентській соціальній групі вона мотивована слабко. Другим чинником дослідниця називає „психологію протесту”, що характерна для металістів: вона зумовлює процеси реномінації, серед психологічних причин якої - „бажання виразити своє відмінне світосприйняття за допомогою відмінних засобів”. До лінгвальних чинників зарахований принцип мовної економії. І. Приходько визначає такі головні причини використання мовцями сленгової лексики: прагнення до експресії вислову; потреба показати в жар-

2 Д. С. Лихачев, Черты первобытного примитивизма воровской речи, [в:] Язык и мьлиление, Москва-Ленинград 1935, т. 3-4, с. 52.

${ }^{3}$ М. А. Грачёв, указ. источник, с. 110.

${ }^{4}$ Д. С. Лихаче в, указ. источник, с. 55-68.

5 Л. А. Радзих ов ский, А.И. Мазурова, Сленг как инструмент остранения, [в:] Язык и когнитивная деятельность, Москва 1989, с. 126-137.

${ }^{6}$ Н. О. Ш о в гун, Формування українського сленгу в мовленнєвій діяльності малих соиіальних груn, Автореф. дис. канд. філол. наук, Київ 2000, с. 5.

7 Там само, с. 5-6. 
тівливій формі інтелектуальну перевагу й фантазію, що виявляється в мовній грі; прагнення до протиставлення себе іншим частинам соціуму з метою виділитися; бажання самоствердитися; заперечення традицій. Ці чинники зумовлюють функції молодіжного сленгу: номінативну, комунікативну, корпоративну, самоствердження та головні - емоційно-експресивну й ігрову8.

Отже, як бачимо, різні за структурою соціальні групи характеризуються в наукових роботах різними чинниками поширення й функціонування (розглядаємо їх у комплексі) та зумовленими ними функціями сленгу / жаргону. Очевидно, чинники функціонування й поширення мають позалінгвальну природу, серед яких I. Приходько визначає такі: соціально-психологічний (намагання показати свою причетність до колективних інтересів, бажання не відрізнятися від оточення), урбаністичний (спілкування в широкому колі друзів, які належать до різних соціальних верств), популяризація сленгізмів засобами масової інформації, літературою9. Однак усі вони мають психологічне підгрунтя, так, соціальнопсихологічний, що пов'язаний із корпоративною функцією сленгу, зумовлений психічним механізмом наслідування, який людина реалізує протягом усього життя, але на кожній стадії розвитку по-різному. У поширенні сленгу засобами ЗМІ, літератури тощо працюють механізми зараження й наслідування і т. д.

Мета цієї розвідки - виявити психолінгвальні чинники, адже мова діалектично пов'язана з мисленням і психічною природою людини.

Асоціація як універсальний чинник лінгвокреативного мислення. Лінгвокреативне мислення (Б. Серебренников) $є$, напевне, головним рушієм творення одиниць загального сленгу (як і будь-якого іншого соціолекту). Асоціація загалом є одним із універсальних чинників розвитку й збагачення мови (Й.-Ф. Гербарт, Г. Штейнталь). В. Чабаненко, уточнюючи класифікацію асоціацій Аристотеля (за подібністю, за контрастом, за суміжністю в просторі, за суміжністю в часі), пропонує вирізняти асоціації інтралінгвального та екстралінгвального типів із подальшим структуруванням ${ }^{10}$. Екстраполюючи цю класифікацію на загальний сленг, серед інтралінгвальних асоціацій виділяємо асоціації за змістом, що забезпечують „зв'язок між усіма компонентами синонімічного ряду" (В. Чабаненко). Одиниці сленгу виявляють парадигматичні відношення всередині підсистеми та стосовно літературної мови, напр., нейтральне алкоголік має такий сленговий синонімічний ряд, позначений емоційністю та експресією: алік, алкалоїд, алкан, алканавт, алкашист, алкашуга, бормотушник, бухарик, бухарін, бухенвальд, бухля, дрінкмен, зюзік, синько, синюк, сливняк, спиртболіст, ханига, забулдига. Показовим у цьому плані $\epsilon$ „Покажчик синонімів” у словнику Л. Ставицької „Український жаргон” (Київ, 2005). Другим виявом асоціації за змістом $\epsilon$, на думку В. Чабаненка, зв'язок між усіма варіантами полісемантичного слова. Загальний сленг і тут має свою специфіку: 1) розвиток нового лексико-семантичного варіанта (далі - ЛСВ) сленгового значення в давньої субстандартної одиниці (напр., арготизми отримують нові переосмислені значення в молодіжному або загальному сленгу), 2) розвиток сленгового значення в літературного слова, напр., багатозначна лексема кінчати має такі ЛСВ, засвідчені Словником української мови в 11 томах: „1) доводити що-небудь до кінця; докінчувати, завершувати, закінчувати; 2) роби-

${ }^{8}$ I. Г. При ходько, Російський молодіжний сленг Києва (кінець XX-початок XXI cm.), Автореф. дис. канд. філол. наук, Київ 2006, с. 5.

${ }^{9}$ Там само, с. 8.

${ }^{10}$ В. А. Ча баненко, Асоціайія як універсальний чинник мовного розвитку, [в:] „Мовознавство”, 2005, № 3-4, с. 134. 
ти що-небудь на закінчення; завершувати чимось; 3) припиняти у визначений час роботу, навчання тощо; закінчувати; 4) розм. Позбавляти життя, вбивати"11. Так само і у Великому тлумачному словнику сучасної украӥнської мови (укладач В. Бусел, 2005). У молодіжному сленгу другий ЛСВ літературного слова отримав семантичний розвиток унаслідок перенесення у фізіологічну площину: „відчувати оргазм”"12, „досягати оргазму в статевому акті”13. Згодом лексема в сленговому значенні набула значного поширення, а отже, ввійшла до загального сленгу, вживається найчастіше в усно-побутовому та Інтернет-дискурсі на форумах відповідної тематики, мовленні персонажів художнього твору: Бронька підтримував руками сідницю, шкутильгаючи добирався до дивана, зганяв обмащеного зеленкою, у виразках Лопату: „Ну щзо? Хто краще кінчив... Ото о-о-о” (О. Ульяненко, Сталінка, 2003).

На основі інтралінгвальних асоціацій за функцією відбувається процес стильового й стилістичного перегрупування мовних засобів (В. Чабаненко), що в загальному сленгу виявляється в переході його одиниць до розмовного шару літературної мови та розвитку сленгових значень на базі літературних слів.

Спосіб бачення світу відтворюють у мові асоціації екстралінгвального типу. Так, за співвідношенням із зовнішнім світом визначають асоціації істинні й фіктивні. Другий тип у загальному сленгу репрезентований, по-перше, сленгізмами, що виникли внаслідок фонетичної мімікрії (гера, герасим - героїн, Білочка - Біла Церква Київської області, чайковський / чайкоффрський — чай), що в мовленні отримує стійкий асоціативний зв'язок (напр., „Чайкофффський” назва кав'ярні в Дніпропетровську), а по-друге, сленгізмами, що первісно виникли в арго, однак через псевдопрозору внутрішню форму, що викликає асоціацію з літературним словом, набули поширення в молодіжному або загальному сленгу, напр., сленгізм жара зафіксований в такому значенні: „напружена, емоційно насичена ситуація" "14, асоційований з літературним уживанням: „Гаряча літня пора; спека // Висока температура повітря в приміщенні, печі i т. ін." ${ }^{15}$, розвиток значення в уявленні пересічних носіїв сленгу відбувається в такому напрямі: спека $\rightarrow$ висока температура $\rightarrow$ накалювання $\rightarrow$ емоційне накалювання $\rightarrow$ напружена ситуація. Однак первісно ця лексема $є$ арготизмом у значеннях: „1) безвихідь, 2) сигнал небезпеки"16. Б. Ларін констатує, що в арго це калька з німецької мови: Kühle - тюремне ув'язнення ${ }^{17}$. Д. Лихачов указує на зв'язок уявлень про жару, гаряче з уявленням про небезпеку ще в мові офенів, де рос. прогореть - розоритися, порівн. спільні позначення поняття „бути переслідуваним" в англ. та рос. мовах: англ. to be in hot water, hot, poc. nozopeть - бути впійманим, пожар — арешт, баня — допит, сжечь - видати ${ }^{18}$.

Спільні асоціації в кримінальних арго Д. Лихачов пояснює спільними суспільними зв'язками й спільними соціальними умовами, що продукують один i той самий тип мислення. Дослідник наводить як приклад одне з найважливіших для злодія поняття —,,тюрма”, що у всіх мовах відтворює подібний образ:

\footnotetext{
${ }^{11}$ Словник украӥнської мови в 11 m., редкол.: акад. І. К. Білодід та ін., Київ 1973, т. 4, с. 167.

12 Л . О . С т а в и ць ка, Украӥнський жаргон: словник, Київ 2005, с. 173.

${ }^{13}$ Словник сучасного українського сленгу, упор. Т. М. Кондратюк, Харків 2006, с. 160.

${ }^{14}$ Там само, с. 124.

${ }^{15}$ Словник української мови..., т. 2, с. 509.

${ }^{16}$ М. А. Грач е в, Толковый словарь русского жаргона, Москва 2006, с. 181.

${ }^{17}$ Б. А. Л ар ин, Западноевропейские элементы русского воровского арго, [в:] „Язык и литература", Ленинград 1931, т. 7, с. 126.

18 Д. С. Лихаче в, указ. источник, с. 54.
} 
англ. academy, college, big school, фр. collège, lycée, pension, seminaire, poc. академия, университет ${ }^{19}$. Універсальність асоціації проявляється в найменуванні міських об'єктів. М. Грачов указує на таку особливість арготичної лексики, як наявність у ній арготопонімів і наводить приклади: рос. савел прокофьич Савелівський вокзал, плешка Краснушка - Червона площа (арготизм плеш$\kappa a$ - площа), Финбан - Фінляндський вокзал (арготизм бан — вокзал), большая жмурня - міський морг (арготизм жмурня - морг) та ін. ${ }^{20}$. Порівняймо зі сленговими топонімами - вони перебувають у периферійній зоні загального сленгу: Хряків - місто Харків, Бахчипариж - місто Бахчисарай АР Крим, Бандерштадт - місто Львів, Х'юстон - місто Хуст Закарпатської області.

Цікаві асоціативні паралелі знаходимо в уживанні кольоративів як сленгізмів: голубий - гомосексуаліст, голубізна - гомосексуальні стосунки, $\phi i-$ олетово - байдуже, сленгізм-калька: зелені - долари. Особливо виразна й багата соціолектна кольористика в польській мові, напр.: żólty (жовтий) в арго злочинців „злоті”, а żótte kótko - обручка; у мовленні мінял żótty świstek (буквально: жовтий клапоть) - банкнота 1000 злотих ${ }^{21}$, zielenina (зелень) 3 мови мінял „долари"22, niebieski (cuнiü): в арго наркоманів - поставщик наркотиків (той, хто відправляє на небо, тобто доставляє наркотики, що приносять нові відчуття, дають ейфорію, екстаз); niebieski ptaszek wojny в мовленні солдатів - “офіцер, який марнує життя на війні" "23, niebieskie (idiota, obywatel, pajak, piesek, ptaszek) - поліцейський ${ }^{24}$, czarnula - 1) негретоска; 2) дівчина, молода жінка $з$ темним волоссям або темним кольором шкіри ${ }^{25}$, czerwony (червоний): 1) у табірному арго „політичний в'язень”; 2) у конспіративно-партизанському мовленні „партизан Народної Гвардії або Народної Армії”; 3) в арго злочинців „міліціонер”; czerwony pajak (буквально: „червоний павук”), в арго злочинців - „людина партії, комуніст”; czerwony złoty у варшавському просторіччі - „100 злотих"26. Використання механізму асоціації лежить в основі мовної гри - основного способу творення сленгізмів.

Сленг відбиває категорійне мислення людини. За теорією Дж. Лакоффа, принципи категоризації утворюються в процесі осмислення людиною світу й себе в цьому світі, категоризація відбувається на основі досвіду, а досвід людини як фізичної істоти завжди пов'язаний з ії тілесною діяльністю. Цим пояснюється функціонування в мові „тілесних метафор”27. Очевидно, цей принцип поширюється й на „тілесні” сленгізми (булки, сілікон, чайник, радіо, процесор).

Сленг як вияв вербальної свободи. О. Земська пояснювала факт розширення соціальної бази сленгу його використанням як розвінчування догм тоталітарного режиму, висміювання лозунгів епохи соціалізму ${ }^{28}$, однак це більшою мірою стосувалося 1990 -х років у зв'язку з актуальністю соціально-політичних перетворень у країні. Цікаву думку щодо вербальної свободи наводить С. КараМурза: вивільнення слова „означало перш за все усунення святості, іскри бо-

${ }^{19}$ Там же, с. 53-54.

${ }^{20}$ M. А. Гр ачёв, указ. источник, с. 120.

${ }^{21}$ S . K a ni a, Słownik argotyzmów, Warszawa 1995, s. 264.

${ }^{22}$ Tamże, s. 259.

${ }^{23}$ Tamże, s. 147.

${ }^{24}$ M. C z e s z ew s k i, Słownik slangu młodzieżowego, Piła 2001, s. 164.

${ }^{25}$ Tamże, s. 40.

${ }^{26}$ S . K a ni a, Słownik argotyzmów, Warszawa 1995, s. 65.

27 Дж. Лакофф, Мымиение в зеркале классификаторов, [в:] Новое в зарубежной лингвистике, Москва 1988, вып. XXIII, с. 12-51.

${ }^{28}$ Е. А. Зе м ская, Язык как деятельность: Морфема. Слово. Речь, Москва 2004, с. 373. 
жої - десакралізащію. <..> Слово, ім'я переставало потаємно виражати сховану в речі першопричину". Такий розрив слова й речі дослідник називає культурною мутацією, унаслідок якої слово стає цілком автономним від моралі, адже свобода мислення передбачає гарантію відсутності наслідків за висловлене, написане ${ }^{29}$. I хоча таке розуміння свободи слова $є$ абсолютизованим, однак воно цілком відповідає постмодерній масовій свідомості, підтвердженням чого $\epsilon$ формат Інтернет-комунікації в чатах і форумах, а найвищий вияв має у флеймі - свідомому й безвідповідальному у зв'язку з анонімністю ображання інших комунікантів чату / форуму з метою розпалювання чвари.

Функціональний вияв одинцць загального сленгу й обсценної лексики. Більшість лінгвістичних словників обходять поняття „обсценна лексика” або „нецензурна лексика”, даючи визначення тільки поняттю ,лайлива лексика”, що однак, як зауважує В. Мокієнко, не є цілком ідентичним, оскільки не все лайливе - обсценне ${ }^{30}$. До обсценної лексики (від лат. obscenus - непристойний) відносимо непристойні слова й вислови, що містяться у сфері дії нормативних рекомендацій і заборон, але ця умова їхнього функціонування все частіше порушується, зокрема в сучасних художніх творах, причому не тільки прозових (порівняймо, напр., поезію С. Жадана, насичену обсценною лексикою). У повсякденно-побутовій культурі її називають матом.

Лексема мат засвідчена Великим тлумачним словником сучасної украӥнської мови як жаргонізм у значенні „вульгарна лайка”з1, у Словнику української мови в 11-ти томах це значення не зафіксоване. Однак через поширеність лексеми в розмовному мовленні та у зв'язку із цим експресивності й уживанням у номінативній функції на позначення вульгарної лайки вважаємо, що це слово перейшло до розряду просторічних, як воно наведене, скажімо, в тлумачному словнику російської мови С. Ожегова зі стилістичною позначкою „просторічне”: „непристойно-огидлива лайка зі згадуванням слова мать"з2. Щоправда, таке тлумачення звужує коло матірної лексики, адже вона об'єднана семантикою сексуальної тематики, що зумовлено психологічними механізмами, які лежать в основі її вживання. У психології константним параметром використання обсценної лексики називають конфронтацію, протистояння, суперництво, причому як з індивідом / індивідами, так і з матеріальним світом. Така ситуація породжує відчуття страху, загрози „Я” бути позбавленим меж індивідуальності, бути поглиненим кимось чужим - увесь цей комплекс відчуттів, разом із передчуттям поразки, дестабілізують психологічне функціонування особистості, активують архетипний комплекс стосунків „батько - син” (К. Юнг), психоаналіз якого детально розроблений 3. Фрейдом. Отже, в стадії конфронтації індивід асоціює себе із сином, якого пригноблює грізний батько, тож його природною реакцією буде самозахист, зокрема вербальний у вигляді матірної лексики (тут має місце прояв міфологічного мислення - віра в магічну силу слова), що ніби перевертає ситуацію догори ногами, перебираючи на себе домінантну роль грізного батька (детальніше про семіотику ситуацій із використанням різних матірних висловів див. у Б. Успенського (1994), М. Маковського (1997)). Як наслідок індивід відчуває послаблення внутрішньої напруги, яке

${ }^{29}$ С. Г. Кара-Мурза, Манипуляичия сознанием, Москва 2004, с. 87-88.

${ }^{30}$ В . М. Мок и е н ко, Русская бранная лексика: изензурное и нецензурное, [в:] „Русистика” Берлин 1994, № 1-2, с. 55.

${ }^{31}$ Великий тлумачний словник сучасної украӥнської мови, уклад. і голов. ред. В. Т. Бусел, Київ-Ірпінь 2005, с. 651.

${ }^{32}$ С. И. О жего в, Словарь русского языка, Москва 2008, с. 451. 
3. Фрейд пов'язує з принципом задоволення. Отже, функцією вживання обсценної лексики є миттєвий підсвідомий захист цілісності „Я”з3. Д. Лихачов відзначає гіпертрофію матірної лайки в кримінальному середовищі, причому вона ні до кого не звернена (матірну лайку, спрямовану на злодія, сприймають як кривду, яку можна змити тільки кров’ю) - у ній утілене „прагнення зробити своє мовлення дієвим і активним" 34 . Ситуація вживання евфемістичних сленгізмівзамінників матірної лексики (піnещь, капець, блін, довбаний, грьобаний) має в основі ті самі психологічні механізми захисту, однак індивід усвідомлює табуйованість цієї лексики й свідомо пом'якшує ситуацію. Свідоме використання сленгізмів $\epsilon$ проявом мовної гри в рекреативному аспекті. Експлетивне вживання обсценної лексики також має психологічну природу: „індивід зберігає позитивний досвід використання обсценізмів, за допомогою яких раніше була отримана перемога (i, відповідно, задоволення), та застосовує його в позаконфліктних ситуаціях, - таким чином, принцип задоволення без особливих зусиль вирішує будь-які ситуації, у чому досягає ступеня ритуальності”"35.

Так само і в ситуацях неусвідомленого вживання експлетивного сленгізму блін. Це підтверджує й проведене Ю. Низкодуб у 2007-2008 рр. соціолінгвістичне опитування серед студентської молоді віком 16-19 років міста Луганська, Україна (такий вибір респондентів зумовлений тим, що студенти - найбільш здатна до самоаналізу й інтелектуальної рефлексії група молоді, а також тим, що саме в студентському віці завершується процес формування ідеалів і смаків, зокрема й мовних). Мета опитування - вивчення суб'єктивної думки студентів про лихослів'я в різних комунікативних ситуаціях. Результати автор інтерпретує шляхом складання мовленнєвих портретів, що визначені за професійною й гендерною ознаками: дівчата-педагоги, хлопці-педагоги (студенти ЛНПУ імені Тараса Шевченка), дівчата-непедагоги, хлопці-непедагоги (студенти Політехнічного коледжу Луганського національного аграрного університету). У мовленні всіх груп респондентів, незалежно від їхнього ставлення до лихослів'я (до речі, чоловічі групи виправдовують уживання обсценної лексики в стресових ситуаціях), засвідчена сленгова лексика в ролі нецензурної, зокрема лексеми рос. блин, пипец, ё-моё ${ }^{36}$. Погоджуємося з В. Мокієнком, який уважає, що „мат, як і жаргон, став своєрідною модою”з7, причому сама модність перейшла у звичку, ритуал, а тому сленгізми-евфемізми в мовленні втрачають не тільки семантичне наповнення, але й емоційно-експресивне навантаження.

Здійснений теоретичний аналіз психолінгвальних чинників поширення й функціонування сленгізмів має прикладне застосування у визначенні в різних типах дискурсів сугестивних потенцій лексичних і фразеологічних одиниць сленгу, способів їх використання в рекламі (на різних етапах реалізації маркетингової формули AIDA), в політичному дискурсі, зокрема в реалізації тактик самопрезентації та дискредитації опонента тощо.

${ }^{33}$ О. С. Чабан, А. Б. Коваленко, Теоретическое моделирование функиий неформальной лексики (аналитический взгляд), [в:] „Таврический журнал психиатрии” 2003, т. 7, № 1 (22), с. 76.

${ }^{34}$ Д. С. Лих ачев, указ. источник, с. 58.

${ }^{35}$ О. С. Чабан, А. Б. Ковален ко, зазн. джерело, с. 76.

${ }^{36}$ Ю. В. Ни з коду б, Современная молодёжь: речевые портреты на фоне сквернословия, [в:] Равноправие украинского и русского языков - основа консолидации народа Украины, Луганск 2009, с. 148-153.

${ }^{37}$ В. М. Мокие нко, указ. источник, с. 53. 